\title{
Study of Student's Attitude TOWARDS NeW TeCHNOLOgICAL Contexts AND Neuroscience Progress
}

Fátima Llamas-Salguero ${ }^{1}$, Pilar Martín-Lobo ${ }^{2}$, Silvia Pradas-Montilla ${ }^{3}$ y Marta Gil-Nájera $^{2}$

\author{
${ }^{1} \mathrm{PhD}$ in Science of Education. Professor, Department of Psychology of Education and Psychobiology. \\ E-mail:fatima.llamas@unir.com \\ ${ }^{2}$ PhD in Psychology. Neuropsychology Applied to Education Research Group \\ ${ }^{3} \mathrm{PhD}$ in Science of Education. Neuroplasticity and Learning Research Group \\ Universidad Internacional de la Rioja, Logroño, Spain
}

Received date: August 5, 2016 Accepted date: October 28, 2016

How to cite this article: F. Llamas-Salguero, P. Martín-Lobo, S. Pradas-Montilla, \& M. Gil-Nájera, "Study of Student's Attitude Towards New Technological Contexts and Neuroscience Progress", Ingeniería Solidaría, vol. 13, no. 21, pp. 27-36, January 2017. doi: http://dx.doi.org/10.16925/in.v13i21.1725

\begin{abstract}
Introduction: Technology and Neuroscience have formed a strong collaboration to improve education. The effective use of information and communication technologies (ICT) in education practice requires that both students and teachers maintain a positive attitude towards these technologies, and develop their use in educational contexts to update teaching methodologies based on educational neuroscience and neuropsychology. Thus, the use of ICT requires a positive attitude when using these tools during the teaching-learning process, as a starting point to improve the quality of the process. The article was written in the year 2016 in the faculty of Education of the Universidad Internancional de la Rioja. Methodology: The aim of this study is to analyze the student's attitudes towards the use of new technologies in primary school classrooms. We designed a questionnaire and gave it to 1,770 students aged 11 and 12 years from 50 CEIP (Infant and Primary schools). Results: In general, the results show that whilst students of 11 and 12 years do not show a rejection of the use of ICT, a low percentage demonstrate that they would prefer to use them in a group. Conclusions: An adequate use of ICT in the classroom would depend on the predisposition of the students, and the knowledge of the technologies and their use by teachers and students. Therefore, it is recommended for ICT to be implemented in the classroom in order to improve the teaching-learning process and to incorporate new methodologies from neuroscience research.
\end{abstract}

Keywords: ICT, innovation, learning, neuropsychology, student, teacher. 


\section{ESTUdio DE LA ACTITUd ESTUdIANTIL FRENTE A NUEVOS CONTEXTOS TECNOLÓGICOS Y EL PROGRESO DE LA NEUROCIENCIA}

Resumen. Introducción: la tecnología y la neurociencia se han cohesionado fuertemente para colaborar con la mejora en la educación. El uso efectivo de las tecnologías de la información y la comunicación (TIC) en la práctica educativa requiere que los estudiantes y profesores mantengan una actitud positiva hacia estas tecnologías y desarrollen su uso en contextos educativos para actualizar metodologías de enseñanza basadas en neurociencia y neuropsicología educativa. Por lo tanto, el uso de las TIC demanda una actitud positiva al utilizar estas herramientas durante el proceso de enseñanza-aprendizaje, como punto de partida para mejorar la calidad del proceso. Este artículo fue escrito en el 2016 en la Facultad de Educación de la Universidad Internacional de la Rioja. Metodología: el objetivo de este estudio fue analizar las actitudes de los estudiantes hacia el uso de las nuevas tecnologías en las aulas de la escuela primaria. Diseñamos un cuestionario y lo entregamos a 1770 estudiantes entre los once y doce años de edad de cincuenta CEIP (escuelas infantiles y de primaria). Resultados: en general, los resultados muestran que aun cuando los estudiantes entre los once y doce años no muestran un rechazo al uso de las TIC, un bajo porcentaje preferiría usarlas en un grupo. Conclusiones: un uso adecuado de las TIC en el aula dependería de la predisposición de los alumnos, así como del conocimiento de las tecnologías y de su uso por parte de profesores y estudiantes. Por lo tanto, se recomienda implementar las TIC en el aula para mejorar el proceso de enseñanza-aprendizaje y para incorporar nuevas metodologías de la investigación en neurociencia.

Palabras clave: TIC, innovación, aprendizaje, neuropsicología, estudiante, profesor.

\section{ESTUDO DA ATITUDE ESTUDANTIL DIANTE DE NOVOS CONTEXTOS TECNOLÓGICOS E O PROGRESSO DA NEUROCIÊNCIA}

Resumo. Introdução: a tecnologia e a neurociência têm se mantido coeso para colaborar com a melhoria da qualidade na educação. O uso efetivo das tecnologias da informação e da comunicação (TIC) na prática educativa requer que os estudantes e os professores preservem uma atitude positiva diante dessas tecnologias e desenvolvam seu uso em contextos educativos para atualizar metodologias de ensino baseadas em neurociência e neuropsicologia educativa. Portanto, o uso das TIC demanda de uma atitude positiva ao utilizar essas ferramentas durante o processo de ensino-aprendizagem como ponto de partida para melhorar a qualidade do processo. Este artigo foi escrito em 2016 na Faculdade de Educação da Universidad Internacional de la Rioja. Metodologia: o objetivo deste estudo foi analisar as atitudes dos estudantes diante do uso das novas tecnologias nas salas de aula dos primeiros anos do ensino fundamental. Desenhamos um questionário que foi aplicado a 1770 estudantes entre onze e doze anos de idade de cinquenta CEIP (escolas infantis e de ensino fundamental). Resultados: em geral, os resultados mostram que, ainda quando os estudantes entre onze e doze anos não mostram uma rejeição ao uso das TIC, uma baixa porcentagem preferiria usá-las num grupo. Conclusões: um uso adequado das TiC na sala de aula dependeria da predisposição dos alunos bem como do conhecimento das tecnologias e de seu uso por parte dos professores e dos estudantes. Portanto, recomenda-se implantar as TIC na sala de aula para melhorar o processo de ensino-aprendizagem e para incorporar novas metodologias da pesquisa em neurociência.

Palavras-chave: TIC, innovação, aprendizagem, neuropsicologia, estudante, professor. 


\section{Introduction}

In recent years, cognitive neuroscience and technology have been developing in parallel and collaborating closely [1]. The use of neuronal imaging techniques, along with other types of electrophysiological techniques makes it possible to obtain new scientific knowledge for a better understanding of brain processes. It also allows us to know in which part of the brain (along with when and how) these processes are integrated in order to better perform learning processes [2]. As an example, we can find several studies concerned with global functional connectivity [3], the neural correlates of the action denomination and spatial relationship [4], or the relationship between the neural substrate related to the sense of touch and object recognition [5]. As research progresses, some techniques have been used to run a cross validation of several techniques such as electroencephalogram (EEG) and RNMF (magnetocephalography) that allow a better understanding of brain functioning [6]. These technological advances favor, not only the development of knowledge about brain function, but also an understanding of the complexity of the information processing involved in attention, memory, thinking skills and learning that require the synchronization of a multiple neuronal network. Access to this information by the teacher opens up the possibility of applying neuropsychological progress to the educational context, including programs to develop multiple intelligence [7], neuropsychology and technology programs to improve language difficulties [8], or programs applying neuropsychology to schools at different ages. Some studies have shown an improvement in processes such as attention, motivation, and memory in university students when technology is used based on neuroscience strategies [9]. When referring to attitudes, decision-making and emotions, there are also a number of studies based on the use of technologies. An example of this can be found in the study by Greene, Sommerville, Nystrom, Darley and Cohen [10], which examined the role of emotion on moral judgment using RNMF.

\subsection{Neuropsychology and Technology in Students aged 11 and 12}

The neurofunctional basis of cognitive and emotional learning allows us to have a perspective of the brain as a functional support for learning, and it particularly allows us to apply technological methodologies in the classroom [11]. It is therefore relevant to know the neurodevelopmental characteristics of the students included in this work in order to use technology from the neuropsychological perspective. The development of their brain functionality shows that during this period (11-12 years) they are capable of processing information in different areas of the brain at the same time, in order to integrate and coordinate the information. This complex information processing requires a certain degree of brain development and myelination of neurons, along with an increase of neurotransmitters in the synaptic processes [12]. When observing children of this age using technology, we can appreciate the high degree of interest that it generates, along with the implications of the tasks and multitasking actions that they are required to perform. Further, this is a period involving better comprehension, memorizing and organizing, for which it is necessary that they develop the frontal lobe areas and integrate information through the hard body that links both hemispheres [13]. When technological methodologies are applied considering these facts, it helps the teacher make decisions regarding the use of technology as an efficient tool for neurodevelopmental progress rather than as mere entertainment. At this age the reading and comprehension speed increases due to binocular reading using both eyes, which allows for higher precision and higher visual, visuo-spatial and visuo-motor skills that are developed between 6 and 11 years of age, and that continue to develop thereafter [14]. A further important aspect worth considering is attention. Between the ages of 9 and 12 years, children develop attentional control processes that improve selective attention [15], and attentional difficulties are due to a lack of development of the frontostriatal circuit that is responsible for inhibitory control (and that continues to develop during adolescence), rather than due to selective immaturity [16]. Technology can facilitate the development of selective attention and focusing when doing homework as well as working memory, given that during this age grey matter increases in parietal and frontal areas that are involved in this type of memory process [17].

\subsection{Neurotechnology}

Over the last few years, technology has been incorporated into the classroom, and is now believed to be present in every school. As early as the 1970s, 
some authors suggested that adaptation to the environment in the digital era entails training and using new technologies in all the subjects in schools [18]. However, in order to use them correctly, we need to know the effects that they can have on the generation of knowledge, and therefore establish the relevance of training teachers and understanding the development of knowledge when interacting with technologies. Based on these suggestions, our study aims to incorporate educational neurotechnology into our educational and neuropsychological research. We therefore find a bridge between two relevant areas of study for the educational context: neuropsychology and technology. These areas offer the opportunity to promote a more successful learning experience. Educational neurotechnology focuses on the use of technology in the educational context by also analyzing neural processing. It can therefore be regarded as a new science of learning based on the knowledge of the brain and the methodology used when including technology in the classroom context [11].

This methodology focuses more on "how" learning occurs rather than "what" is being learned. In the current context we can find a high diversity of sources of information, news, data and an overabundance of information, and we require a learning approach focused on inquiry, coordination and dynamic articulation processes of knowledge to solve problems rather than simply acquiring fixed knowledge. The key is to know the advantages of using technology for our brain, as well as to discover its drawbacks, in order to develop new strategies. For instance, Small [19] suggested that whilst the use of the Internet has a positive impact on brain functioning, it is problematic when overused. Individuals that spend around ten hours per day using the computer can show a reduced aptitude for interpersonal contact, such as keeping a conversation face to face. Small [19] also suggested that the Internet has changed not only the way people produce and create content, but also the way they communicate and experience enjoyment. The Internet also alters brain functioning [19].

We should take into account that when using technology, the effect of stimulus-response takes place at a speed that does not occur in the analogic context. The success achieved when playing videogames, for instance, is due to the decisions we make. Linehan, Lawson and Doughty [20] developed a serious game designed to improve behavior when making collaborative decisions. The game MetaVals aims to develop collective decision-making processes in pairs [21]. It is critical to understand that with the use of technology we can maximize the sensory information that we receive through multimedia sources. This allows the stimulation and potentiation of the capacities of both hemispheres, stimulating both ways of thinking in order for them to complement each other. This in turn would help to fulfill the great potential of the human brain in a holistic way.

\subsection{Technology Application and Development}

In order to use this progress and apply innovative programs, education that uses ITC should offer the conditions required to optimize the teaching-learning process, promote knowledge transfer, and incorporate new skills. Attitude is one important issue that should be taken into account in studies about learning contexts [22]. Learning contexts should reflect the anticipated use of new knowledge in order to avoid the loss of acquired knowledge [23-24]). When implementing ITC, the educational context should also be adequate, providing and preserving the links with the context outside the classroom. Moreover, the teachers should promote the student's participation with a positive attitude when using the ITC, and also favor active construction of knowledge. This requires an open learning space instead of a mere transference of facts [22, 25-26]. Cooperation and interaction in the classroom are also important to promote the acquisition of learning skills, problem solving skills, and social relations [27-29]. Finally, given that we can find differences in skills and perception in the classroom towards the use of ICT, these differences should be considered as key criteria for an effective teaching-learning process in the classroom [30-32]. Thus, the responsible authorities should adapt the educational context to the needs and capacities of the individual students.

ITC can contribute to the creation of powerful learning contexts in various ways. In particular, ICT offer opportunities to access a vast quantity of information through multiple resources, along with various ways to visualize this information from different perspectives. ITC can also make complex problems easier to understand through simulations that promote the creation of an optimum learning context [33]. Moreover, ITC can also be an 
instrument for curricular differentiation, offering opportunities to adapt learning content and tasks to the specific needs and skills of each student, and offering tailored information [34-35].

However, some studies show that the approach in schools is focused on the use of ICT based on traditional knowledge [35-38]. A recent study about the impact of ICT on student performance (including 60 schools) showed that the percentage of lessons that included ICT was generally low. And whilst some links were found between the amount of use of ICT and student's performance, this relationship was not consistent across all the different levels.

\subsection{Programs of Educational Neuropsychology using Technology}

Educational neuropsychology programs train visual, auditory and perceptive skills, and sensory integration and lateral development in order for the brain hemisphere to provide good integration and comprehension of incoming information. These programs also improve linguistic and thinking skills, memory and creativity, all of which favor neurodevelopment and learning [39]. These processes can be trained with technology using educational neurotechnology programs [11]. Further, the students show an attentional affinity towards technology that facilitates creating strategies to access information and new neural circuits for learning, this is possible due to the young brain's plasticity [19]. Students also display a profile that has both the necessary skills and interest for using technology [40]. This allows the use of neurotechnology to improve school performance from a neuropsychological perspective. Increasing the number of studies in this area will open up new lines of educational and methodological research. A first step in this analysis is to study the attitudes of students towards technology.

\section{Methodology: Experimental Design}

The present study aims to analyze students' attitude towards the use of new technologies in a Primary School classroom. The study made use of a questionnaire methodology. The questionnaire was given to a sample of 1,770 students (Table 1 ) of 11-12 years old from 50 different CeIP (Infant and Primary schools).
We employed a questionnaire with closed questions which had two possible outcomes: "Positive" and "Negative", and several open questions that allowed the participant to provide more detailed information and opinions related to educational contexts and technologies applied to education.

The question in the questionnaire was: What do you think of Information and Communication Technologies? This question was also related to other guided open questions to corroborate the students' perception towards ICT, with the following study indicators: comprehension of the tools and applications; possibilities to use it as a future working tool; accessibility for students and teachers; interaction in the classroom; active communication; speed and easiness of use, and educational support.

The questionnaires were given to the students in order to know their attitude, given that, with this information, we could change, modify, or develop different teaching methodologies using ITC as a support to generate new knowledge for the students. The sample analyzed in this study was composed of students from $6^{\text {th }}$ grade Primary School, recruited from various Infant and Primary Schools in Spain.

\subsection{Statistical Analysis}

We made use of spss 13 (Windows version) package for the statistical analysis. As a preliminary step, we analyzed the normality and homogeneity of the variances. In addition, we ran a descriptive analysis of the sample. For each of the analyses, we considered the number of valid cases, excluding cases with lost data. The frequency tables display the absolute frequency of the valid cases for each of the variables (frequency), percentage frequency (percentage), percentage frequency of the valid cases, that is, eliminating cases with lost data (valid percentage) and the accumulated percentage frequency (accumulated percentage).

Table 1. Sample distribution

\begin{tabular}{|l|c|l|c|}
\hline & Frequency & & Percentage (\%) \\
\hline Male & 921 & & 52 \\
\hline Female & 818 & & 46.2 \\
\hline Total & 1,739 & & 98.2 \\
\hline Lost data & 31 & & 1.8 \\
\hline Total & 1,770 & & 100 \\
\hline
\end{tabular}

Source: Compiled by the authors 
As a measure of the relationship between the variables evaluated in the frequency tables, we used the Chi-square statistical analysis. A p $<0.05$ value indicated that the variables were related (for some results we also provide the Likelihood ratio). For each relationship of interest, the statistical analysis is provided, with a significance level predetermined at $\mathrm{p}<0.05$. Once the relationship between two nominal variables was obtained, we evaluated the strength of this relationship using the contingency coefficient. When appropriate, we compared the mean values -for instance the male and female student's age-using a T Students for independent samples. For all of the cases we adopted a significance level of confidence of $95 \%$, and all cases with lost data were excluded. We applied the Levene (F) test as well as the $T(t)$ statistics, degrees of freedom (df), the bilateral significance, the means differences for each group, and also applied the typical error of the mean difference.

\section{Results}

After analyzing the student's responses to the open questions, they were asked to respond to the question: "What do you think about the Information and Communication Technologies? It was found that $86.3 \%$ (1,527 of 1,770 students) of the sample answered with a generally positive opinion of ICT. Their answers to the open questions included the following comments: "They are important because we learn easily and they are fun"; "They allow us to do many things"; "They are fun"; "They are easy to use"; "They provide a higher diversity of activities, and they are useful to gather information easily"; "They are quicker"; "They are important to communicate with others"; "They support the study process". Apart from the most common answers as seen above, some students pointed out that there are insufficient technological tools in their school or that they are not in use.

The students with negative attitudes to ICT accounted for $5.4 \%$ of the total sample (96 of 1,770 students). On the basis of these results, we can conclude that the majority of students take a positive stance towards ICT. Amongst the negative answers given by the students, some examples included: "We don't know much about them, They can be addictive"; "They are OK, but I prefer the text book for some things"; "They are a waste of time". These answers are of interest because they show that some students do not have enough knowledge about ICT, given that in some schools ICT tools are not implemented, or if they are implemented, they are not in use or are only used to project video. Under these circumstances, the students would not be expected to be aware of their functionality or potential educational value. One of the answers that is of special interest is "They can be addictive". The students are familiar with the use of ICT in their homes without much control other than that of the family. The teachers, however, can offer some guidance in the classroom about the function and use of the tools by using, for instance, programs for learning how to interact with ICT guides for Internet surfing, social networks, and various types of games. A percentage of the sample, $8.2 \%$ (146 of the total 1,770) did not answer this question.

The students' attitude obtained from the data in this study is somewhat puzzling, given that not all of the students indicated that they like ICT, whilst some did not understand the use of ICT in the classroom as being something positive. Only $60 \%$ of the sample stated that they like to use ICT in the teaching-learning process, are motivated by its use, have a better understanding of concepts, and like to write essays with these tools. These data are surprisingly low, given that ICT technologies appear to be generally welcomed by schools (Table 2).

We also analyzed gender differences in an attempt to examine whether they reflect some of the stereotypical views held in society regarding the use of ICт by male and female children -for example that boys like ICT more than girls. A total of $52 \%$ (921 of the 1,770) were male, whereas $46.2 \%$ (812 of the 1,770) were female. Subsequent analysis of these differences revealed that there were no significant differences in the general perception of the use of ICT, but there were significant differences regarding the positive or negative value of these technologies (Table 3). 
Table 2. Student's attitudes towards ICT

\begin{tabular}{|l|c|c|c|c|}
\hline \multicolumn{1}{|c|}{ Items } & \multicolumn{3}{c|}{ Percentage (\%) } \\
\cline { 2 - 5 } & DA & N & A & CA \\
\hline I like using ICT as a tool in teaching and learning & 40 & 0 & 0 & 60 \\
\hline I don't like to use ICT as a tool in teaching and learning & 40 & 40 & 10 & 10 \\
\hline I am very motivated with the use of ICT in teaching and learning & 10 & 10 & 20 & 60 \\
\hline I like to participate in classes when using ICT & 30 & 0 & 20 & 50 \\
\hline I like to present work with ICT in the classroom as they are very easy to use & 30 & 0 & 10 & 60 \\
\hline With ICT I can understand the concepts more efficiently & 20 & 0 & 20 & 60 \\
\hline When I use ICT my attention in class increases & 20 & 10 & 20 & 50 \\
\hline
\end{tabular}

DA: Disagree; N: Neutral; A: Agree; CA: Completely Agree

Source: Compiled by the authors

Table 3. Chi-Square Tests

\begin{tabular}{|l|l|l|l|}
\hline & \multicolumn{1}{|c|}{ Value } & \multicolumn{1}{c|}{ Df } & \multicolumn{1}{|c|}{ Asymp. Sig. (2-sided) } \\
\hline Pearson Chi-square & $1.685^{*}$ & 2 & 0.431 \\
\hline Likelihood Ratio & 1.701 & 2 & 0.427 \\
\hline Linear-by-Linear Association & 1.676 & 1 & 0.195 \\
\hline N of Valid Cases & 1,739 & 0 & 0 \\
\hline
\end{tabular}

* 0 cells $(0 \%)$ have expected count less than 5 . The minimum expected count is 6.92

Source: Compiled by the authors

\section{Discussion and Conclusions}

The importance that we assign to the use of ICT is of considerable significance [41]. Our results show that even in schools that have an equivalent ICT system in place, students perceive these technologies differently in terms of availability and use from other related tools. In particular, students can be categorized into two groups according to the type of answer given. Those that say that "The tools in the school are not enough and not used", and those that perceive that the infrastructure available is adequate and that "The ICT tools are important because we learn easily and have fun"; "They allow us to do many different things"; "We understand them"; "They are easy to use"; "They provide a wider range of activities"; "They support our study".

The attitude that students have towards the use of ICT has a significant impact on the learning context, and this attitude is defined by different factors. The teachers' skills in terms of the use of ICT play an important role [42-43]. Another aspect that could influence this attitude is the ease with which the students are able to access ICT [44-45]. This refers not only to the number of computers per student, but also to the positioning of the computer station, for example, the computer room or the classroom. Kennewell et al. [44] considered crucial to place computers in the classroom so as to maximize the opportunities for ICT to be part of the curricular activities. These authors suggested that the number of computers, however, is less important.

Additionally, the teachers' pedagogical perspectives and their point of view about how ICT can contribute to the learning context play an important role in the real use of ICT in the classroom [46-49]. Switching towards a learning context focused on the students, and where teachers create the intellectual learning context is of particular interest. This applies specially to open learning contexts [50-51].

Another factor to take into account is the possible difference with regard to the use of ICT determined by gender. It has been suggested that female children have a less positive attitude towards ICT than male children [52-54]. However, we found no significant differences related to gender when analyzing the closed question about attitude towards ICT. This could be due to the small differences 
obtained with young adults [55-56]. The students in our study displayed, in general, positive responses regarding the use of Iст. The students that showed a negative attitude towards the use of ICT accounted for only a low percentage of our sample, particularly with regard to attention, motivation, and a deeper understanding of concepts. We did, however, find a high percentage of respondents with a positive attitude towards the tools and applications, the speed and ease of use of ICT, the confidence of its use at work, the ease of understanding and learning, the interaction in the classroom, or active communication and educational support. This result is not surprising if we consider the preference that young students show towards technology [40]. These results could be explained in terms of an increased need to train the teachers and update their knowledge of technological progress and methodological changes that come from neuropsychology and technological research studies. This new knowledge could be implemented in the classroom context to innovate and improve educational experiences in the classroom.

We can draw several conclusions from our data regarding students' attitude and their perception of the use and influence of ICT in the classroom. All the schools that participated in this study had the same technological facilities, and the pattern of responses was, in general, similar across the schools, regardless of the use of the ICT in the different centers. The students' opinion towards ICT is, in general, positive, and we found no gender differences in the responses of our participants.

Whilst the students' attitude towards the technological tools is generally positive, their evaluation of the ICT use in the classroom is particularly low. The participants in this study do not regard the use of ICT in the classroom to be adequate, and do not believe that ICT tools could function as a support for improving the understanding of concepts, attention, or acquisition of knowledge. On the basis of these findings, both educational authorities and teachers should tailor the use of ICT to the individual needs of each technological-educational context when incorporating ICT into the teaching-learning process. The unique requirements of each context would be provided by individualized assessments.

A future perspective could start and focus on developing educational neurotechnology programs for neuropsychological skills training along with programs based on the findings from neurosciences and neuropsychology in order to develop the student's potential. In addition, these should be adapted to the needs of each educational context to improve the quality of the teaching-learning process.

\section{References}

[1] P. Enríquez et al., Neurociencia cognitiva: una introducción. Madrid: UNED, 2006, pp. 10-229.

[2] R. Llinás, El cerebro y el mito del yo. Bogotá: Norma, 2002, p. 287.

[3] C. J. Stam \& E. A. de Bruin, "Scalefree dynamics of global functional connectivity in the human brain", Human Brain Mapping, vol. 22, no. 2, pp. 97-109, June, 2004. Available: https://www.researchgate. net/publication/8597479_Scalefree_dynamics_of_ global_functional_connectivity_in_the_human brain

[4] H. Damasio et al. , "Neural correlates of naming actions and of naming spatial relations", NeuroImage, vol. 13, pp. 1053-1064, 2001.

[5] C. L. Reed, S. Shoham \& E. Halgren, "Neural substrates of tactile object recognition: An fMrI study", Human Brain Mapping, vol. 21, pp. 236-246, 2004.

[6] E. Martínez-Montes, P. A. Valdés-Sosa, F. Miwakeichi, R. I. Goldman \& Y. Yamaguchi, Y. "Concurrent EEG/ fMrI analysis by multiway partial least squares”, NeuroImage, vol. 22, pp. 1023-1034, 2004.

[7] M. L. García \& F. Llamas-Salguero, "Procesos y programas de Inteligencias Múltiples", in Procesos y programas de neuropsicología educativa, P. Martín-Lobo Coord., Madrid: Ministerio de Educación Nacional, Centro Nacional de Investigación e Innovación Educativa, 2015, pp. 123-138.

[8] S. Pradas \& C. de la Peña, "Programas para superar las dificultades de lenguaje", in Procesos y programas de neuropsicología educativa, P. Martín-Lobo Coord., Madrid: Ministerio de Educación Nacional, Centro Nacional de Investigación e Innovación Educativa, 2015, pp. 164-176.

[9] J. L. Jaramillo Enciso, "Neurociencia y gestión de tecnologías de información para la educación". Master thesis in Administración de Tecnologías de Información, Instituto Tecnológico y de Estudios Superiores, Monterrey, México, 2004. Available: http://repositorio.educacionsuperior.gob.ec/handle/28000/1339

[10] J. D. Greene, R. B. Sommerville, L. E. Nystrom, J. M. Darley \& J. D. Cohen, "An fMrI investigation of emotional engagement in moral judgment", Science, vol. 293, pp. 2105-2108, 2001. 
[11] S. Pradas, Neurotecnología educativa, Madrid: Ministerio de Educación Nacional. Centro Nacional de Investigación e Innovación Educativa, 2016.

[12] A. Bressler, "In Understanding cognition through large-scale cortical networks", Curr Dir Psychol Sci, vol. 11, pp. 58-61, 2002.

[13] J. Ferré \& M. Ferré, Neuro-psico-pedagogía infantil. Bases neurofuncionales del aprendizaje cognitivo $y$ emocional. Barcelona: Lebón, 2013, p. 400.

[14] S. M. Bova et al., "The development of visual object recognition in school age children", Dev Neuropsychol, vol. 31, pp. 79-102, 2007.

[15] M. Goldberg, D. Maurer \& T. Lewis, "Development changes in attention the effects of endogenous cueing and of distracters", Dev Sci, vol. 4, pp. 209-219, 2001.

[16] J. R. Booth et al., "Neural development of selective attention and response inhibition", Neuroimage, vol. 20, pp. 737-751, 2003.

[17] P. Campo et al., "Time modulated prefrontal and parietal activity during the maintenance of intagrated information as revealed by magnestoencephalografy", Cerebr cortex, vol. 15, pp. 123-130, 2005.

[18] M. Donaldson, La mente de los niños, Madrid: Morata, 1979, pp. 8-188.

[19] G. Small, El cerebro digital. Cómo las nuevas tecnologías están cambiando nuestra mente, Barcelona: Urano, 2009, p. 256.

[20] C. Linehan, S. Lawson \& M. Doughty, “Tabletop Prototyping of Serious Games for 'Soft' Skills Training", in Proceedings of 1st International Conference in Games and Virtual Worlds for Serious Applications, Coventry, United Kingdom, Mar. 23-24, 2009, pp. 182-185.

[21] M. Romero, M. Usart \& E. Almirall, "Serious games in a finance course promoting the knowledge group awareness", in EDULEARN11 Proceedings, 3rd International Conference on Education and New Learning Technologies, Barcelona, Spain, Jul. 3-4, 2011, pp. 3490-3492.

[22] A. Collins, "Design issues for learning environments", en International perspectives on the design of technology-supported learning environments, S. Vosniadou Ed., Mahwah, NJ: Lawrence Erlbaum, 1996, pp. 347-361.

[23] J. D. Bransford, R. D. Sherwood, T. S. Hasselbring, C. K. Kinzer \& S. M. Williams, "Anchored instruction: why we need it and how technology can help", in Cognition, education, multimedia. Exploring ideas in high technology, D. Nix \& R. Spiro Eds., Hillsdale, NJ: Lawrence Erlbaum Associates, 1990, pp. 115-141.

[24] T. M. Duffy \& R. A. Knuth, "Hypermedia and Instruction: Where is the match?", in Designing hyper- media for learning, D. Jonassen \& H. Mandl Eds., Berlin: Springer-Verlag, 1990, pp. 199-225.

[25] M. J. Hannafin, C. Hall, S. Land \& J. Hill, "Learning in open-ended environments: assumptions, methods and implications", Educational Technology, vol. 34, no. 8, pp. 48-55, 1994.

[26] D. H. Jonassen, K. L. Peck \& B. G. Wilson, Learning with technology: A constructivist perspective, Upper Saddle River, NJ: Merrill, 1999.

[27] N. Bennett \& E. Dunne, “The nature and quality of talk in co-operative classroom groups", Learning and Instruction, vol. 1, pp. 103-118, 1994.

[28] R. E. Slavin, Cooperative learning: theory, research and practice, $2^{\text {nd }}$ ed., Boston: Allyn and Bacon, 1995.

[29] E. B. Susman, "Co-operative learning: a review of factors that increase the effectiveness of computer-based instruction", Journal of Educational Computing Research, vol. 18, no. 4, pp. 303-322, 1998.

[30] E. Bearne, Ed., Differentiation and diversity in the primary school, London: Routledge, 1996.

[31] T. Kerry \& A. Kerry, “Differentiation: teachers' views of the usefulness of recommended strategies in helping the more able pupils in primary and secondary classrooms", Educational Studies, vol. 23, no. 3, pp. 439-457, 1997.

[32] M. C. Wang, "Learning characteristics of pupils with special needs and the provision of effective schooling”, in Special education: Research practice: synthesis of findings, M. C. Wang, M. C. Reynolds \& H. J. Walberg, Eds., New York: Pergamon Press, 1990, pp. 1-34.

[33] F. Llamas-Salguero, Repercusiones del uso de las Tecnologías de la Información y la Comunicación en la adquisición de conocimientos en los alumnos de Educación Primaria. Prospectiva para la formación de maestros, Madrid: UCM, 2013.

[34] T. Mooij, "Guidelines to Pedagogical Use of ICT in Education", in 8th Conference of the 'European Association for Research on Learning and Instruction' (EARLI), Göteborg, Sweden, Aug. 1999.

[35] E. Smeets \& T. Mooij, "Pupil-centred learning, ICT, and teacher behaviour: observations in educational practice", British Journal of Educational Technology, vol. 32, no. 4, pp. 403-418, 2001.

[36] T. W. Chalkley \& D. Nicholas, “Teachers' use of information technology: observations of primary school classroom practice", Aslib Proceedings, vol. 49, no. 4, pp. 97-107, 1997.

[37] J. Richardson, Information Technology - a new path to creativity in education, Paris: Editions ESKA, 1997.

[38] D. Williams, L. Coles, K. Wilson, A. Richardson \& J. Tuson, “Teachers and Iст: current use and future 
needs", British Journal of Educational Technology, vol. 31, no. 4, pp. 307-320, 2000.

[39] P. Martín-Lobo, "La intervención desde la base neuropsicológica y metodologías que favorecen el rendimiento escolar", in Procesos y programas de neuropsicología educativa, P. Martín-Lobo Coord., Madrid: Ministerio de Educación Nacional, Centro Nacional de Investigación e Innovación Educativa, 2015, pp. 14-27

[40] G. Roca, Soluciones para nuevas realidades. Modelos de negocio en las redes sociales, Madrid: Telos, 2008.

[41] C. Harrison et al., ImpaCT2. The Impact of Information and Communication Technologies on Pupil Learning and Attainment. ICT in Schools Research and Evaluation Series - No. 7. Coventry: British Educational Communications and Technology Agency, 2002.

[42] E. Smeets et al., The Impact of Information and Communication Technology on the Teacher, Nijmegen, the Netherlands: University of Nijmegen, ITs, 1999.

[43] W. Veen, "Factors affecting the use of computers in the classroom: four case studies", in Integrating information technology into education, D. Watson \& D. Tinsley, Eds., London: Chapman \& Hall, 1995, pp. 169-184.

[44] S. Kennewell, J. Parkinson \& H. Tanner, Developing the ICT capable school, London: Routledge Falmer, 2000 .

[45] отA, Teachers and Technology: making the connection, Washington DC: Office of Technology Assessment, Congress of the United States/U.s. Government Printing Office, 1995.

[46] H. Drenoyanni \& D. Selwood, "Conceptions or misconceptions? Primary teachers' perceptions and use of computers in the classroom", Education and Information Technologies, vol. 3, pp. 87-99, 1998.

[47] S. Higgins \& D. Moseley, “Teachers' thinking about Information and Communications Technology and Learning: beliefs and outcomes". Teacher Development, vol. 5, no. 2, pp. 191-210, 1998.
[48] B. Hokanson \& S. Hooper, "Computers as cognitive media: examining the potential of computers in education", Computers in Human Behavior, vol. 16, pp. 537-552, 2000

[49] D. S. Niederhauser \& T. Stoddart, “Teachers' instructional perspectives and use of educational software", Teaching and Teacher Education, vol. 17, no. 1, pp. 15-31, 2001.

[50] R. D. Hannafin \& W. C. Savenye, "Technology in the classroom: the teacher's new role and resistance to it", Educational Technology, vol. 33, no. 6, pp. 26-31, 1993.

[51] C. M. Keeler, "Networked instructional computers in the elementary classroom and their effect on the learning environment: a qualitative evaluation", Journal of Research on Computing in Education, vol. 28, no. 3, pp. 329-345, 1996.

[52] B. Huber \& J. W. Schofield, "I like computers, but many girls don't. Gender and the sociocultural context of computing", in Education/technology/Power. Educational computing as a social practice, $\mathrm{H}$. Bromley \& $\mathrm{M}$. W. Apple, Eds., Albany: State University of New York Press, 1998, pp. 103-132.

[53] V. Makrakis \& T. Sawada, "Gender, computers and other school subjects among Japanese and Swedish pupils", Computers and Education, vol. 26, no. 4, pp. 225-231, 1996.

[54] M. Volman, "Gender-related effects of Information and Computer Literacy Education", Journal of Curriculum Studies, vol. 29, no. 3, pp. 315-328, 1997.

[55] Ch. Comber, A. Colley, D. J. Hargreaves \& L. Dorn, "The effects of age, gender and computer experience upon computer attitudes", Educational Research, vol. 9, no. 2, pp. 123-134, 1997.

[56] A. Durndell, P. Glissov \& G. Siann, "Gender and computing: Persisting differences”, Educational Research, vol. 37, no. 3, pp. 219-227, 1995. 